\title{
Extended programmes: widening participation by narrowing content
}

\author{
Dawn Reilly, Jing Luo, Wenxian Sun, Liz Warren \\ University of Greenwich
}

Keywords: Business Education, extended programmes, year zero, foundation year, widening participation

In September 2016, the University of Greenwich Business School introduced its first portfolio of extended programmes. The majority of these programmes followed a common initial year, referred to for the remainder of this opinion piece as 'year zero'. The programme design for year zero was intended to launch students on their programme of study by introducing basic academic writing and communication skills, while also including general business-related content. On extended programmes, the benefits of generic foundation years such as year zero include the efficient use of resources. As all students are studying the same modules, it is easier for universities to forward-plan and to run larger lectures than would be possible if each programme had its own year zero with smaller student numbers. The reasons for the Business School's approach to programme design for this new initiative were therefore obvious and logical. There were economies of scale to be had, especially by basing year zero on existing foundation modules already available within the University, as the programmes could be set up relatively swiftly for the initial cohorts. This was very helpful, because, as these students would be recruited through Clearing 2016, there was no clear idea of expected numbers in the early stages of the recruitment cycle. However, in this piece, we argue that a bespoke year zero design, with a focus on a narrower range of subject-specific topics, enhances the experience of the students on our extended programmes and is worth the investment.

The use of the plural 'cohorts' in the previous paragraph is deliberate, as it gets to the nub of the problem we encountered. Whilst, in the early days, we may have referred to all 'extended students' en masse, the students did not see themselves as a single group of 'general business' students. Their programme identities and departments were very important to them. Although the programme structures were set out clearly on the University's website, the students had not anticipated a quasi-generic foundation year plus three years; they had enrolled on to a four-year extended programme commencing with year zero. The students expected programme-specific content from the outset and, from the feedback we received from the first few weeks of term onwards, it became apparent that something had to be done. This opinion piece represents the views of colleagues from three departments within the Business School and demonstrates how we took a united approach to resolving the problem which we all encountered.

Our response was twofold. First, we regarded the feedback as reflecting a serious and immediate problem, which we addressed by adding previously unplanned extra-curricular content into the year. One example was a trading competition in term one. In term two, the department with the highest number of extended students provided four weeks of taught sessions to its students on a programme-specific topic. This content, not assessed, was of a 
technical nature and attendance was voluntary, but the fact that attendance proved to be excellent demonstrated both that students considered this topic crucial and that they appreciated access to subject-specific content in year zero. Our second response was therefore a complete re-design of the Business School's extended programmes.

With an eye on cost efficiencies, we retained some common modules for all of the School's extended students. However, each department now also offers significant bespoke content during year zero. Students achieve academic skills and familiarisation with the University's support services and systems via a new extended project module, which exposes students under the guidance of their personal tutor during timetabled project classes - to an academic research opportunity in their chosen discipline. The discipline-specific modules are particularly popular with our extended students and feedback in liaison meetings and via online module surveys suggests that they have had a largely positive experience over the past two years. The results on the online feedback forms changed from very concerning to excellent after the implementation of the design.

During the re-design, the team asked not only 'What do the students want?', but also 'What do the students need?'. Many of the students on our extended programmes join us following disappointing results from A levels or alternative qualifications. To work at a university that embraces widening participation by providing these students with the opportunity to pursue higher education in their chosen field is a privilege and something we should all be proud of, but it also brings a responsibility: The students of course want - and deserve - to study the subjects they have chosen, but it is essential to consider precisely what year zero should include to prepare the students, not only to progress from year zero but also to achieve well in year one when they join the new students who enrol on our three-year programmes. It is the performance of these students in year one (as well as how they compare with their direct-entry peers) that serves as the 'critical test' for extended programmes (Harwood, 2016, p.16). Although the students come to us with lower entry qualifications, we have failed them if they feel they are the weakest students once they enter year one.

Bandura's (1997) theory of 'self-efficacy' emphasises the importance of a student's belief in himself or herself to achieve a certain goal, such as passing year one. Without this, the determination to overcome obstacles and challenges is diminished, making positive achievement less probable. The modules in the new year zero have therefore been designed to expose students to some year one content, thereby affording them a 'foundation' of relevant knowledge, laid in the foundation-type extended year and building confidence about what to expect in future. In this way, we hope to build up perceived selfefficacy for students whose previous level 3 qualifications may have made them question their self-belief. We also include exposure to a range of assessment styles in year zero, including one or two exams (in relevant programmes) where this method of assessment will be used in year one. Introducing exams in this way helps to build self-confidence as students see that they can achieve in an academic context, that they have the skills required to revise for exams and that they are ready to progress to the next stage of their programmes (Pearce et al., 2015).

The challenge for students with low entry qualifications is to achieve a good degree, despite their grades at school and college. The challenge for us as educators is to design extended programmes which help students to achieve. Our experience over the past three years 
suggests that a bespoke year zero design, with a focus on a narrower range of subjectspecific topics, has the potential to help us to meet that challenge and therefore merits the additional investment when compared to a generic provision.

\section{Reference list}

Bandura, A. (1997) Self-efficacy: the exercise of control. New York, NY: W.H. Freeman and Company. ISBN: 9780716728504.

Harwood, D. (2016) 'Extended science: a powerful tool in widening participation.' Journal of Learning Development in Higher Education, 10. ISSN: 1759-667X Available at:

http://journal.aldinhe.ac.uk/index.php/ildhe/article/view/263 (Accessed: 20 December 2019).

Pearce, H., Campbell, A., Craig, T., le Roux, P., Nathoo, K. and Vicatos, E. (2015) 'The articulation between the mainstream and extended degree programmes in engineering at the University of Capetown: reflections and possibilities.' South African Journal of Higher Education, 29(1), 150-163. Available at: https://journals.co.za/content/high/29/1/EJC172793 (Accessed: 20 December 2019). 